\title{
The Delta Factor
}

When the facts change, I change my mind. Author disputed

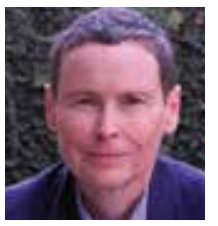

Cynthia Geppert is Editor-in-Chief; and Professor and Director of Ethics Education at the University of New Mexico School of Medicine in Albuquerque. Correspondence: Cynthia Geppert (fedprac@mdedge.com)

Fed Pract. 2021;38(9). Published online September 12. doi:.10.12788/fp.0181 $0^{b}$ everal weeks ago, I received a call from my brother who, though not a health care professional, wanted me to know he thought the public was being too critical of scientists and physicians who "are giving us the best advice they can about COVID. People think they should have all the answers. But this virus is complicated, and they don't always know what is going to happen next." What makes his charitable read of the public health situation remarkable is that he is a COVID-19 survivor of one of the first reported cases of Guillain-Barre syndrome, which several expert neurologists believe is the result of COVID-19. Like so many other COVID-19 long-haul patients, he is left with lingering symptoms and residual deficits. ${ }^{1}$

I use this personal story as the overture to this piece on why I am changing my opinion regarding a COVID-19 mandate for federal practitioners. In June I raised ethical concerns about compelling vaccination especially for service members of color based on a current and historical climate of mistrust and discrimination in health care that compulsory vaccination could exacerbate. ${ }^{2}$ Instead, I followed the lead of Secretary of Defense J. Lloyd Austin III and advocated continued education and encouragement for vaccine-hesitant troops. ${ }^{3}$ So in 2 months what has so radically changed to lead Secretary Austin and US Department of Veterans Affairs (VA) Secretary Denis R. McDonough to mandate vaccination for their workforce? $?^{4,5}$

I am calling the change the Delta Factor. This is not to be confused with the spy-thrillers that ironically involved rescuing a scientist! The Delta Factor is a catch-all phrase to cover the protean public health impacts of the devastating COVID-19 Delta variant now ravaging the country. Depending on the area of the country as of mid-August, the Centers for Disease Control and Prevention (CDC) estimated that $80 \%$ to $>90 \%$ of new cases were the Delta variant. ${ }^{6}$ An increasing number of these cases sadly are in children. ${ }^{7}$

According to the CDC, the Delta variant is more than twice as contagious as index or sub- sequent strains: making it about as contagious as chicken pox. The unvaccinated are the most susceptible to Delta and may develop more serious illness and risk of death than with other strains. Those who are fully vaccinated can still contract the virus although usually with milder cases. More worrisome is that individuals with these breakthrough infections have the same viral load as those without vaccinations, rendering them vectors of transmission, although for a shorter time than unvaccinated persons. ${ }^{8}$

The VA first mandated vaccination among its health care employees in July and then expanded it to all staff in August. ${ }^{9}$ The US Department of Defense (DoD) mandatory vaccination was announced prior to US Food and Drug Administration's (FDA) full approval of the Pfizer-BioNTech vaccine. ${ }^{10}$ Secretary Austin asked President Biden to grant a waiver to permit mandatory vaccination even without full FDA approval, and Biden has indicated his support, but the full approval expedited the time line for implementation. ${ }^{11}$

Both agencies directly referenced Delta as a primary reason for their vaccination mandates. The VA argued that the mandate was necessary to protect the safety of veterans, while the DoD noted that vaccination was essential to ensure the health of the fighting force. In his initial announcement, Secretary McDonough explicitly mentioned the Delta variant as a primary reason for his decision. noting "it's the best way to keep veterans safe, especially as the Delta variant spreads across the country." Similarly, Secretary Austin declared, "We will also be keeping a close eye on infection rates, which are on the rise now due to the Delta variant and the impact these rates might have on our readiness." 5

VA and DoD leadership emphasized the safety and effectiveness of the vaccine and urged employees to voluntarily obtain the vaccine or obtain a religious or medical exemption. Those without such an exemption must adhere to masking, testing, and other restrictions. ${ }^{5}$ As anticipated in the earlier editorial, there has been opposition to the mandate from the workforce 
of the 2 agencies and their political supporters some of whom view vaccine mandates as violations of personal liberty and bodily integrity and for whom rampant disinformation has amplified entrenched distrust of the government. ${ }^{12}$

The decision to shift from voluntary to mandatory vaccination of federal employees responsible for the health care of veterans and the defense of citizens, which may seem draconian to some, is grounded in core public health ethical and legal principles. The first is the doctrine of the least restrictive alternative, which dictates that implemented public health policies should have the least infringement on individual liberties as possible. ${ }^{13} \mathrm{~A}$ corollary is that less coercive methods should be reasonably attempted before moving to more restrictive policies. Both agencies have struggled somewhat unsuccessfully to vaccinate employees even with extensive education, persuasion, and incentives. In July, the active-duty vaccination rates ranged from 58 to $77 \%$; among VA employees it ranged from 59 to $85 \%$, depending on the facility. ${ }^{14}$

Finally and most important, for a vaccine or other public health intervention to be ethically mandated it must have a high probability of attaining a serious purpose: here preventing the harms of sickness and death especially in the most vulnerable. In July, the White House COVID-19 Response Team reported that "preliminary data from several states over the last few months suggest that $99.5 \%$ of deaths from COVID-19 in the United States were in unvaccinated people" and were preventable. ${ }^{15}$ Ethically, even as mandates are implemented across the federal workforce, efforts to educate, encourage, and empower vaccination especially among disenfranchised cohorts must continue. But as a recently leaked CDC internal document acknowledged about the Delta Factor, "the war has changed" and so has my opinion about mandating vaccination among those upon whose service depends the life and security of us all. ${ }^{16}$

\section{Disclaimer}

The opinions expressed herein are those of the author and do not necessarily reflect those of Federal Practitioner, Frontline Medical Communications Inc., the US Government, or any of its agencies.

\section{References}

1. CBS Good Morning. Christopher Cross on his near-fatal COVID illness. Published October 18, 2020. Accessed August
21, 2021. https://www.cbsnews.com/news/christopher-cross -on-his-near-fatal-covid-illness

2. Geppert CM. Mistrust and mandates: COVID-19 vaccination in the military. Fed Pract. 2021;38(6):254-255. doi:10.12788/fp.0143

3. Garmone J, US Department of Defense. Secretary of defense addresses vaccine hesitancy in the military. Published February 25, 2021. Accessed August 23, 2021. https://www.defense .gov/Explore/News/Article/Article/2516511/secretary-of -defense-addresses-vaccine-hesitancy-in-military

4. US Department of Veterans Affairs, Office of Public and Intergovernmental Affairs. VA mandates COVID-19 vaccines among its medical employees including VHA facilities staff [press release]. Published July 26, 2021. Accessed August 21, 2021. https://www.va.gov/opa/pressrel/pressrelease .cfm?id=5696

5. US Department of Defense, Secretary of Defense. Memorandum for all Department of Defense employees. Published August 9, 2021. Accessed August 23, 2021. https://media .defense.gov/2021/Aug/09/2002826254/-1/-1/0/MESSAGE -TO-THE-FORCE-MEMO-VACCINE.PDF

6. Centers for Disease Control and Prevention COVID data tracker. Variant proportions. Updated August 17, 2021. Accessed August 23, 2021. https://covid.cdc.gov/covid-data -tracker/\#variant-proportions

7. American Academy of Pediatrics. Children and COVID-19: state data level report. Updated August 23, 2021. Accessed August 23, 2021. https://www.aap.org/en/pages/2019-novel -coronavirus-covid-19-infections/children-and-covid-19-state| -level-data-report

8. Centers for Disease Control and Prevention. Delta variant: what we know about the science. Update August 19, 2021. Accessed August 23, 2021. https://www.cdc.gov /coronavirus/2019-ncov/variants/delta-variant.html

9. US Department of Veterans Affairs, Office of Public and Intergovernmental Affairs. VA expands mandate for COVID-19 vaccines among VHA employees [press release]. Published August 12, 2021. Accessed August 23, 2021. https://www .va.gov/opa/pressrel/pressrelease.cfm?id=5703

10. US Food and Drug Administration. FDA approves first COVID19 vaccine [press release]. Published August 23, 2021. Accessed August 23, 2021. https://www.fda.gov/news-events /press-announcements/fda-approves-first-covid-19-vaccine

11. Garamone J, US Department of Defense. Biden to approve Austin's request to make COVID-19 vaccine mandatory for service members. Published August 9, 2021. Accessed August 23, 2021. https://www.defense.gov/Explore/News/Article /Article/2724982/biden-to-approve-austins-request-to-make -covid-19-vaccine-mandatory-for-service

12. Watson J. Potential military vaccine mandate brings distrust, support. Associated Press. August 5, 2021. Accessed August 23, 2021. https://apnews.com/article /joe-biden-business-health-coronavirus-pandemic -6a0f94e11f5af1e0de740d44d7931d65

13. Giubilini A. Vaccination ethics. Br Med Bull. 2021;137(1):4-12. doi:10.1093/bmb/ldaa036

14. Steinhauer J. Military and V.A. struggle with vaccination rates in their ranks. The New York Times. July 1, 2021. Accessed August 23, 2021. https://www.nytimes.com/2021/07/01/us /politics/military-va-vaccines.html

15. The White House. Press briefing by White House COVID-19 Response Team and public health officials. Published July 8 , 2021. Accessed August 23, 2021. https://www.whitehouse .gov/briefing-room/press-briefings/2021/07/08/press-briefing -by-white-house-covid-19-response-team-and-public-health -officials- 44

16. Adutaleb $\mathrm{Y}$, Johnson $\mathrm{CY}$, Achenbach J. 'The war has changed': Internal CDC document urges new messaging, warns delta infections likely more severe. The Washington Post. July 29, 2021. Accessed August 21, $2021 \mathrm{https://www.washington}$ post.com/health/2021/07/29/cdc-mask-guidance 